\title{
PHYTO-CHEMICAL ANALYSIS, IN-VITRO ANTIOXIDANT POTENTIAL OF ALOE BARBADENSIS
}

\author{
Shazia Mansoor \\ Department of Research \\ Jawaharlal Nehru Cancer Hospital and Research Centre \\ Bhopal, Madhya Pradesh, India
}

\begin{abstract}
Aloe barbadensis known for centuries for its herbal remedy belongs to the family of Liliaceae. The aqueous and organic leaf extracts were prepared by using soxhlet apparatus. The extracts were evaluated for qualitative phytochemical analysis and its antioxidant property using DPPH radical scavenging assay, alkaline DMSO method, nitric oxide method, Total antioxidant Assay and Deoxyribose method. The present study showed the presence of alkaloid, flavonoid, reducing sugar, terpenoids and steroids by qualitative phytochemical analysis. The aqueous and organic extracts were prepared by using soxhlet apparatus and screened for anti-oxidant property by different methods. The acetone and methanolic extracts $A$. barbadensis showed anti-oxidant activity by DPPH radical scavenging assay with $\mathrm{IC}_{50}$ values of 705.2 \pm 8.08 and $182.8 \pm 1.44 \mu \mathrm{g} / \mathrm{ml}$ respectively. Whereas aqueous and methanolic extracts showed anti-oxidant activity by alkaline DMSO method with $\mathrm{IC}_{50}$ values of $237.5 \pm 11.4$ and $553.4 \pm 3.28$ $\mu \mathrm{g} / \mathrm{ml}$ respectively. While methanolic extract of $A$. barbadensis showed activity by nitric oxide method with $\mathrm{IC}_{50}$ value of $43.17 \pm 6.29 \mu \mathrm{g} / \mathrm{ml}$. The methanolic extract of $A$. barbadensis gave $\mathrm{IC}_{50}$ value of $589.6 \pm 5.54$ by total anti-oxidant activity and aqueous and methanolic extracts gave $\mathrm{IC}_{50}$ value of $579.8 \pm 3.95$ and $714.8 \pm 7.21 \mu \mathrm{g} / \mathrm{ml}$ respectively by deoxyribose method. The presence of these polyphenols may be responsible for its potent anti-oxidant property. The leaf extracts of Aloe barbadensis showed potent anti-oxidant activity and can be used as a therapeutic agent.
\end{abstract}

Keywords - Aloe barbadensis, DPPH, flavanoids and alkaloids

\author{
Huma Mustafa \\ Joint Director \\ Council of Science and Technology \\ Lucknow, Uttar Pradesh, India
}

\section{INTRODUCTION}

Aloe barbadensis belong to the family of Liliaceae and species of succulent plant and the plant is cultivated worldwide. The plant extract of $A$. barbadensis are used widely in herbal products, cosmetics and in medicinal industries. The plant of Aloe barbadensis is succulent short stem plant and grows to a height of about $60-100 \mathrm{~cm}$ (24-39 in) in length and the plant spreads by its offsets. The leaves of $A$. barbadensis are thick and fleshy and color of leaves is green or greyish green. The leaf has a margin which is serrated and has white small teeth ${ }^{(15)}$. The plant is aphrodisiac, hepatic stimulant, stomachic, anti-helmintic, emmenagogue, purgative, hemophilia, wound healing, anti-diabetic and acts particularly on the lower bowels ${ }^{(26)}$. It is also good for skin and skin infections and uterine disorders. The leaves of the plant contains many physiologically and pharmacologically substances which are used as a medicine in spleen enlargement and chronic ulcers ${ }^{(8)}$ and the hot poultice of leaves are used to relieve swelling ${ }^{(3)}$. Many scientists have reported hepatoprotective and anti-oxidant activity in $A$. barbadensis (33, 32). Mohamed (2011) showed hypoglycemic effect in $A$. barbadensis gel extract. It is reported the effect may be due to presence of trace elements, $\mathrm{Zn}, \mathrm{Cr}$ and $\mathrm{Mn}$ in plant, enhances the action of insulin and also attenuates oxidative damage in the serum of alloxan induced diabetic rats which leads to low glucose level ${ }^{(25)}$. Kammoun and his co-workers (2011) believe that there is a significant correlation between the total phenolic content and the anti-oxidant capacity ${ }^{(17)}$. The alcoholic extract showed significantly higher antimicrobial activity ${ }^{(7)}$ also showed anti-oxidant activity by DPPH scavenging assay in crude extract ${ }^{(22)}$ and aloin, active compound of $A$. barbadensis ${ }^{(18)}$. 


\section{METHODOLOGY}

A. Collection and Preparation of plant extract-

The plant leaves were collected from the campus of Integral University, Lucknow. The leaves of the plant were air dried at room temperature and vouchers were sent for identification and stored in National Botanical Research Institute, Lucknow. The dried plant leaves powder was prepared with the help of mortar and pestle and used for extraction in different solvent system using Soxhlet apparatus. The solvents used for extraction were water, benzene, acetone, ethyl acetate and methanol.

\section{B. Phytochemical Analysis (Qualitative) of Plant Extract-}

The phytochemical analysis was carried out to determine the presence of active ingredient of leaf extract. Qualitative estimation of phytochemical analysis has been estimated on the basis of color formation $(12,19,24,9.14)$. The phytochemicals to be determined include alkaloids, anthraquinones, flavonoids, phlobatannins, glycosides, saponins, sterols, tannins, terpenoids and reducing sugar.

\begin{abstract}
Alkaloids
The determination of alkaloids was done by using Wagner's reagent. The preparation of Wagner's reagent was done by dissolving $2 \mathrm{~g}$ of iodine and 6 $\mathrm{gm}$ of potassium iodide in $100 \mathrm{ml}$ of distilled water. The alkaloids were estimated by preparing extract. The extract was prepared by adding $500 \mathrm{mg}$ of dry plant material in $500 \mathrm{ml}$ methanol and it is kept at $37^{\circ} \mathrm{C}$ for $20 \mathrm{~min}$ in water bath. After cooling the extract was filtered and treated with few drops of Wagner's reagent. The appearance of reddish brown precipitate indicated the presence of alkaloids.
\end{abstract}

\section{Anthraquinones (Borntrager's test)}

The extract of the dried leaves of plant were prepared by weighing $0.5 \mathrm{gm}$ and boiled with $10 \%$ hydrochloric acid (HCL) for few minutes in a water bath. The extract was cooled and filtered and to it equal volume of chloroform $(\mathrm{CHCl} 3)$ and few drops of $10 \%$ ammonia was added and heated. The formation of rose pink color indicated the presence of anthraquinones.

\section{Flavonoids}

The presence of flavanoids were determined by preparing methanolic extract, mixed with $10 \mathrm{ml}$ of ethyl acetate and boiled for 3 min over steam bath, cooled and filtered. To $4 \mathrm{ml}$ of filtrate $1 \mathrm{ml}$ of dilute ammonia solution was added. The appearance of yellow color indicated the presence of flavanoids.

\section{Phlobatannins}

The aqueous plant extract was prepared and boiled with $1 \%$ hydrochloric acid $(\mathrm{HCl})$. The deposition of red precipitate confirmed the presence of phlobatannins.

\section{Glycosides (Fehling's Test)}

The extract was prepared by weighing $0.5 \mathrm{gm}$ plant and soaked in $5 \mathrm{ml}$ methanol. The extract was taken 2 $\mathrm{ml}$ and to it $10 \mathrm{ml}$ of $50 \%$ hydrochloric acid $(\mathrm{HCl})$ was added and kept at water bath for $30 \mathrm{~min}$ till boiling. The filtrate was allowed to cool and to it 5 $\mathrm{ml}$ of Fehling's solution was added and boiled for 5 min until brick red precipitate appear. The appearance of brick red color indicated the presence of glycosides.

\section{Saponins (Frothing Test)}

The methanolic leaves extract was prepared and dried at room temperature. The extract of $0.2 \mathrm{gm}$ was shaken with $5 \mathrm{ml}$ of distilled water and boiled. The appearance of creamy mist of small bubbles appearance confirms the presence of saponins.

\section{Steroids (Salkowski Test)}

The methanolic extract was dissolved in methanol and to it 5 drops of concentrated hydrogen sulfoxide $\left(\mathrm{H}_{2} \mathrm{SO}_{4}\right)$ was added. The formation of red color indicated the presence of steroids.

\section{Tannins (Ferric Chloride Test)}

To estimate the presence of tannins methanolic extract of $0.5 \mathrm{~g}$ was weighed and dissolved in $10 \mathrm{ml}$ distilled water, filtered and to it ferric chloride reagent was added. The appearance of blue black precipitate confirms the presence of tannins.

\section{Terpenoids (Salkowski Test)}

The dried leaves of the plant was weighed $0.2 \mathrm{gm}$ and mixed with $2 \mathrm{ml}$ of chloroform and $3 \mathrm{ml}$ of concentrated hydrochloric acid $(\mathrm{HCl})$. The reagents were added carefully to form a layer and appearance of reddish brown coloration of the interface indicated the presence of terpenoids.

\section{Anti-oxidant Assay}

The herbs, spices and medicinal plants have antioxidant property and prevent oxidative stress and increase its protective property. There are number of researchers reported antioxidant property in number of plants. The aqueous and organic extracts were 


\section{International Journal of Engineering Applied Sciences and Technology, 2020 \\ Vol. 5, Issue 7, ISSN No. 2455-2143, Pages 284-291 \\ Published Online November 2020 in IJEAST (http://www.ijeast.com)}

used for screening anti-oxidant assay by different methods.

\section{DPPH (2, 2 - Diphenyl - 1- Picryl Hydrazyl) Radical Scavenging Assay}

The antioxidant property by DPPH radical scavenging assay were determined by the method of Blois (1958) with some modification ${ }^{(6)}$. The dried crude extract prepared in different solvet were weighed at different concentrations varying from $1000 \mu \mathrm{g} / \mathrm{ml}$ to $0.46 \mu \mathrm{g} / \mathrm{ml}$ and dissolved in methanol and used for the experiment. The working solution of DPPH prepared in methanol $100 \mathrm{mM}$. The prepared extract was taken $10 \mu \mathrm{l}$ and mixed with $200 \mu \mathrm{l}$ DPPH and incubated at $37^{\circ} \mathrm{C}$ for $30 \mathrm{~min}$ under dark conditions. Control reaction was prepared by using $\mathrm{L}$-ascorbic acid in place of plant extract. The DPPH radical scavenging activity was determined by measuring the absorbance at $490 \mathrm{~nm}$ spectrophotometrically ${ }^{(4)}$. The percentage inhibitions of samples were calculated by the formula given below.

Scavenging activity $(\%)=$ Absorbance of Control - Absorbance of test x 100 Absorbance of Control

Scavenging of Superoxide Radical with the Alkaline DMSO (dimethyl sulfoxide) Assay

The scavenging of superoxide radical assay with alkaline DMSO were determined by the method of Kunchandy and Rao (1990) with slight modification $(20,31,23)$. The dried plant extract was weighed at different concentrations varies from $1000 \mu \mathrm{g} / \mathrm{ml}$ to $0.46 \mu \mathrm{g} / \mathrm{ml}$ and dissolved in dimethyl sulfoxide. The prepared extract at different concentration were mixed with $0.1 \mathrm{ml}$ of nitro blue tetrazolium $(1 \mathrm{mg} / \mathrm{ml}$ in DMSO) and $1 \mathrm{ml}$ of alkaline DMSO. The alkaline DMSO was prepared by adding $1 \mathrm{ml}$ of DMSO with $5 \mathrm{mM}$ sodium hydroxide and $0.1 \mathrm{ml}$ of water. The final volume was make up to $1.4 \mathrm{ml}$ by adding $0.3 \mathrm{ml}$ of crude extract prepared in DMSO. The absorbance was measured at $560 \mathrm{~nm}$ spectrophotometrically. For Control L-ascorbic acid was used in place of extract. The percentage inhibition was calculated by the formula given below.

Percentage super oxide scavenging activity $=$

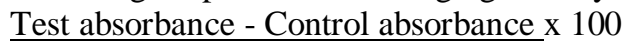
Test absorbance

\section{Nitric Oxide Radial Inhibition Assay}

The dried plant extract was weighed at varying concentrations from $1000 \mu \mathrm{g} / \mathrm{ml}-0.45 \mu \mathrm{g} / \mathrm{ml}$ and dissolved in methanol. The prepared extract of $1 \mathrm{ml}$ was mixed with $1 \mathrm{ml}$ phosphate buffer saline and 4 $\mathrm{ml}$ of $10 \mathrm{mM}$ sodium nitroprusside. The reaction was incubated at $25^{\circ} \mathrm{C}$ for $150 \mathrm{~min}$ and after incubation 1 $\mathrm{ml}$ sulphanilic acid reagent $(0.33 \%$ in $20 \%$ glacial acetic acid) was added and again incubated for $5 \mathrm{~min}$ at room temperature and the process called diazotization reaction. Finally $1 \mathrm{ml}$ of N-(1-naphthyl) ethylenediamine dihydrochloride was added to the reaction mixture and kept for $30 \mathrm{~min}$ in diffused light, after 30 min the absorbance was measured at $540 \mathrm{~nm}^{(5)}$. The control used was L-ascorbic acid.

Scavenging activity $(\%)=$ Absorbance of control Absorbance of extract x 100 Absorbance of control

Total Anti-oxidant Capacity by Phosphomolybdenum Method

The antioxidant assay by phosphomolybdenum method were determined in crude extrct and Lascorbic acid (28). Different concentrations of plant extracts were taken like other assays. The reagent mixture was prepared by taking $0.6 \mathrm{M}$ sulphuric acid, $28 \mathrm{mM}$ sodium phosphate and $4 \mathrm{mM}$ ammonium molybdate. The plant extract $0.1 \mathrm{ml}$ were mixed with $1 \mathrm{ml}$ of reagent mixture and incubated at $95^{\circ} \mathrm{C}$ for 90 $\mathrm{min}$, after incubation the samples were cooled to $25^{\circ}$ $\mathrm{C}$ and absorbance measured at $695 \mathrm{~nm}$ against blank. The blank contained $1 \mathrm{ml}$ of reagent solution without the sample. The results were expressed as absorbance value at $695 \mathrm{~nm}^{(16)}$.

\section{Hydroxyl Radical in the Deoxyribose Method}

The method of Halliwell and co-workers (1987) with slight modifications was used for scavenging of hydroxyl free radical (11). The crude extract of different concentration was prepared in DMSO. The reaction mixture was prepared by adding $0.2 \mathrm{ml}$ $(3 \mathrm{mM})$ deoxyribose, $0.2 \mathrm{ml}(0.1 \mathrm{mM})$ ferric chloride, $0.2 \mathrm{ml}(0.1 \mathrm{mM})$ ethylenediaminetetraacetic acid disodium salt, $0.2 \mathrm{ml}(0.1 \mathrm{mM})$ ascorbic acid and 0.2 $\mathrm{ml}(2 \mathrm{mM})$ hydrogen peroxide in $20 \mathrm{mM}$ phosphate buffer. The extract was added in $0.2 \mathrm{ml}$ reaction mixture to make up volume to $1.2 \mathrm{ml}$ and the sample was incubated at $37^{\circ} \mathrm{C}$ for $30 \mathrm{~min}$. After incubation to the reaction mixture $0.2 \mathrm{ml}(15 \% \mathrm{w} / \mathrm{v})$ chilled trichloroacetic acid, $0.2 \mathrm{ml}(1 \% \mathrm{w} / \mathrm{v})$ thiobarbituric acid dissolved in $0.25 \mathrm{~N}$ hydrochloric acid was added. The sample was kept in boiling water bath for $30 \mathrm{~min}$, cooled and absorbance was measured at 532 $\mathrm{nm}$ spectrophotometrically ${ }^{(13,23)}$. The percentage scavenging were calculated by the formulae given below.

Scavenging activity $(\%)=$ 
Absorbance of Control - Absorbance of test x 100 Absorbance of Control

\section{Statistical Analysis}

All results are expressed as mean \pm standard deviation (SD). The mean, standard deviation and percentage inhibition values were calculated in MS excel. Linear regression analysis was used to calculate the efficient concentration $\left(\mathrm{IC}_{50}\right)$ values.

\section{RESULTS AND DISCUSSIONS}

The crude extract of Aloe barbadensis showed the presence of alkaloid, flavonoid, terpenoids and steroids by qualitative phytochemical analysis. The presence of these phytochemicals like polyphenols and flavonoids in plant plays an important role in reducing risk for chronic diseases and ability to trap highly reactive free radicals species present in biological systems. The presences of these polyphenols are found to be responsible for its antioxidant property ${ }^{(21)}$. In the present study, different aqueous and organic plant extracts were used to evaluate anti-oxidant activity and all showed significant anti-oxidant activity. The number of scientists reported that polyphenols are anti-oxidants with redox properties, which allow them to act as reducing agents, hydrogen donators, and singlet oxygen quenchers. Some show metal chelation properties ${ }^{(29)}$. The anti-oxidant properties were evaluated by DPPH, Alkaline DMSO, Nitric oxide, Total anti-oxidant and Hydroxyl Radical in the Deoxyribose method.

\section{A. DPPH (2, 2 - Diphenyl - 1- Picryl Hydrazyl) Radical Scavenging Assay}

The assay showed the property of crude extracts and standard to scavenge DPPH free radicals. In the DPPH radical scavenging assay, anti-oxidants react with the DPPH radicals exists in stable free radical naturally in deep violet color turns in yellow colored diphenyl picryl hydrazine. The degree of discoloration indicates the radical-scavenging potential of the anti-oxidant ${ }^{(10)}$. The reducing capability of the DPPH is determined by the reduction in its absorbance and was measured at 490 $\mathrm{nm}$ induced by anti-oxidant ${ }^{(6)}$. The $A$. barbadensis methanolic extract showed strongest scavenging activity of $62.9 \pm 0.12$ percent. The other extracts gave their activity in the order of acetone $>$ aqueous extracts and the percentage inhibition was found to be $52.5 \pm 0.25$ and $45.3 \pm 0.22$ percent respectively at $1000 \mu \mathrm{g} / \mathrm{ml}$ concentration of plant extract. The benzene and ethyl acetate extract gave negative result by DPPH assay. The percentage inhibition value of standard, L-ascorbic acid by DPPH method was found to be $78.2 \pm 1.79$ percent at concentration of $1000 \mu \mathrm{g} / \mathrm{ml}$. The values of $A$. barbadensis extracts at different concentrations are shown in graphical representation (Figure 1).

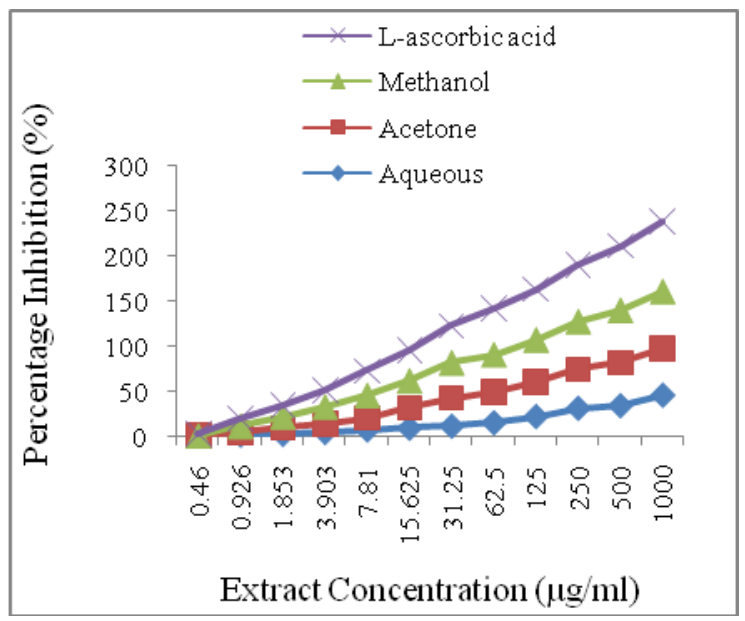

Fig. 1.The scavenging effect of aqueous and organic extracts of Aloe barbadensis and L-ascorbic acid (standard) by DPPH method. The different concentrations of extracts used were 1000 to $0.46 \mu \mathrm{g} / \mathrm{mL}$. The data represent the percentage DPPH inhibition and values are expressed as mean $\pm \operatorname{SD}(n=3)$.

B. Scavenging of Superoxide Radical with the Alkaline DMSO (dimethyl sulfoxide) Assay

The superoxide radicals are known to be very harmful to the cellular component. The superoxide free radical formed by alkaline DMSO in the reaction reacts with Nitro blue tetrazolium (NBT) and produce coloured di formazan which are absorbed at $560 \mathrm{~nm}$ (31). Superoxide anion widely occurs in nature is an important product of one electron reduction of dioxygen $\mathrm{O}_{2}^{-}$. The superoxide ion is a free radical with one unpaired electron and like dioxygen is paramagnetic. The superoxide was a byproduct of mitochondrial respiration mostly by Complex I and Complex III, as well as several other enzymes for example xanthine oxidase. The superoxide radicals are involved to kill and invade micro-organisms by immune system and produced by enzyme NADPH oxidase ${ }^{(23)}$. The methanolic extract of $A$. barbadensis showed strongest anti-oxidant activity, followed by aqueous $>$ acetone $>$ benzene $>$ ethyl acetate extract and the percentage inhibition values were found to be $60.3 \pm 0,57.3 \pm 6.37,45.6 \pm 0.56,44.5 \pm 1.75$ and $34.8 \pm 0.49$ respectively, at the concentration of 1000 $\mu \mathrm{g} / \mathrm{ml}$ of plant extracts. The percentage inhibition 
value of standard, L-ascorbic acid was found to be $54.0 \pm 0.12$ percent at concentration of $1000 \mu \mathrm{g} / \mathrm{ml}$. The percentage inhibition values of $A$. barbadensis extracts by Alkaline DMSO method at different concentrations are shown in graphical representations Figure 2.

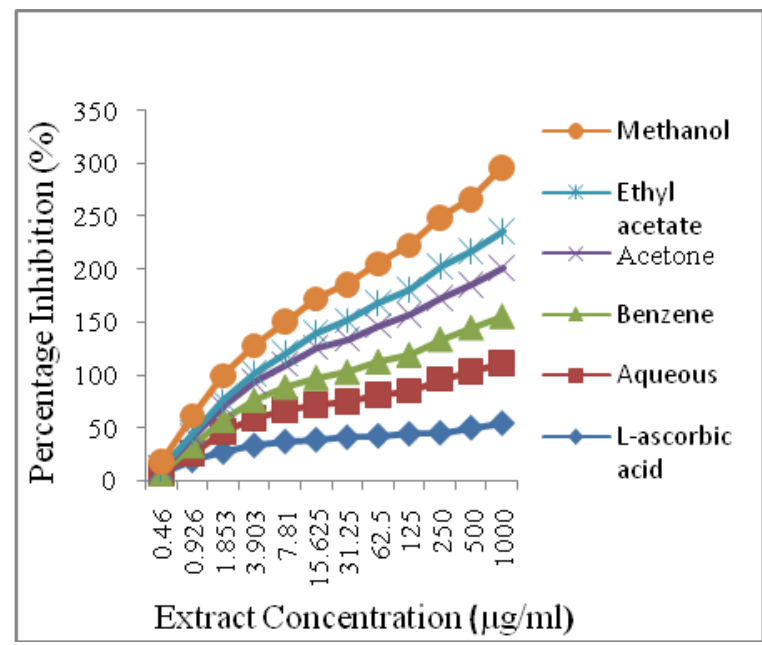

Fig. 2. The scavenging effect of aqueous and organic extracts of Aloe barbadensis and L-ascorbic acid (standard) by Alkaline DMSO method. The different concentrations of extracts used were 1000 to $0.46 \mu \mathrm{g} / \mathrm{mL}$. The data represent the percentage alkaline DMSO inhibition and values are expressed as mean $\pm \mathrm{SD}(\mathrm{n}=3)$.

\section{Nitric Oxide Free Radical Scavenging Assay}

The nitric oxide free radical scavenging activity showed the ability of the extracts and the standard to scavenge nitric oxide free radical. Nitric oxide is unstable under aerobic conditions and reacts with oxygen to reduce stable product nitrates and nitrite through intermediates through $\mathrm{NO}_{2}, \mathrm{~N}_{2} \mathrm{O}_{4}$ and $\mathrm{N}_{3} \mathrm{O}_{4}$. These compounds alter cellular structure and components by causing harm. The test compound scavenge these and decreases the amount of nitrous acid. In above scavenging assay, sodium nitroprusside in aqeous solution and physiological $\mathrm{pH}$ generates nitric oxide which interacts with oxygen to produce nitrite ions and they are scavenged by sample used, this is measured at $540 \mathrm{~nm}$ spectrophotometrically ${ }^{(27)}$. The scavenging of nitric oxide by extracts are concentration dependent. The methanolic extract of A. barbadensis showed strongest activity, followed by ethyl acetate > aqueous $>$ acetone $>$ benzene extract and the percentage inhibition values were found to be $70.2 \pm$ $2.54,47.7 \pm 0.76,43.1 \pm 0.76,41.7 \pm 1.92$ and $22.5 \pm$
2.5 percent respectively, at the concentration of 1000 $\mu \mathrm{g} / \mathrm{ml}$ of plant extracts. The percentage inhibition value of standard, L-ascorbic acid was found to be $84.4 \pm 4.56$ percent at concentration of $1000 \mu \mathrm{g} / \mathrm{ml}$. The percentage inhibition values of $A$. barbadensis extracts by Nitric oxide scavenging assay at different concentrations are shown in graphical representations Figure 3.

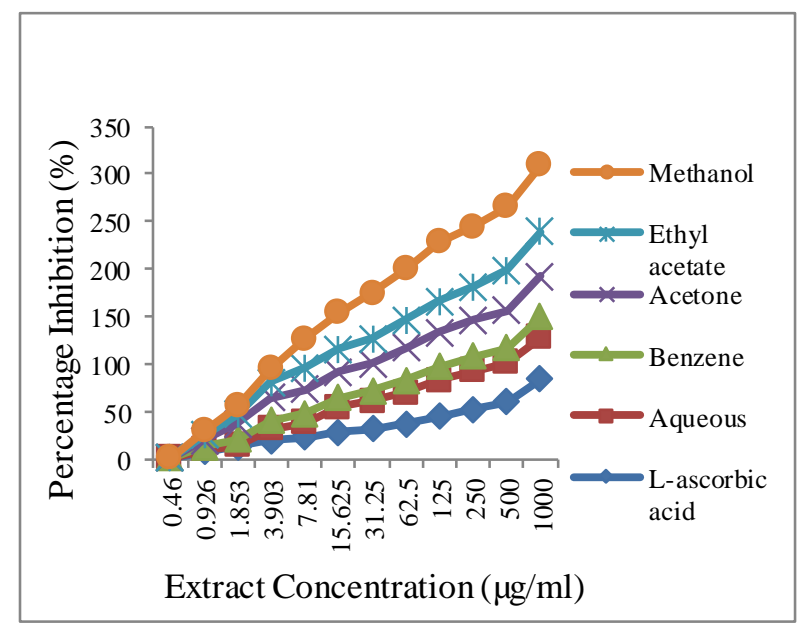

Fig. 3. The nitric oxide radical scavenging activity of aqueous and organic extracts of Aloe barbadensis and L-ascorbic acid (standard). The different concentrations of extracts used were 1000 to $0.46 \mu \mathrm{g} / \mathrm{mL}$. The data represent the percentage nitric oxide inhibition and values are expressed as mean $\pm \mathrm{SD}(\mathrm{n}=3)$.

\section{Total Anti-oxidant Capacity by Phosphomolybdenum Method}

Total anti-oxidant capacities of the plant extracts and L-ascorbic acid were determined by the method of Phosphomolybdenum and measured at $695 \mathrm{~nm}$ spectrophotometrically. The higher absorbance value indicates the greater anti-oxidant activity. The method is based on the reduction of Mo (IV) to Mo (V) by the sample analyte and the subsequent formation of green phosphate/Mo (V) compounds ${ }^{(1)}$. A high absorbance value of the sample indicates its strong anti-oxidant activity. The total anti-oxidant capacity may be attributed to their chemical composition and phenolic acid content. The $A$. barbadensis methanolic extract showed strongest scavenging activity of $58.7 \pm 0.52$ and the other extracts gave their activity in the order of aqueous > acetone $>$ ethyl acetate $>$ benzene extracts and the 
percentage inhibition was found to be $48.1 \pm 2.56$, $34.2 \pm 5.55,34.2 \pm 2.18$ and $18.5 \pm 1.00$ percent respectively at $1000 \mu \mathrm{g} / \mathrm{ml}$ concentration of plant extract. The percentage inhibition value of standard, $\mathrm{L}$-ascorbic acid was found to be $73.3 \pm 1.15$ percent at concentration of $1000 \mu \mathrm{g} / \mathrm{ml}$. The percentage inhibition values of $A$. barbadensis extracts by Phosphomolybdenum method at different concentrations were shown in Figure 4.

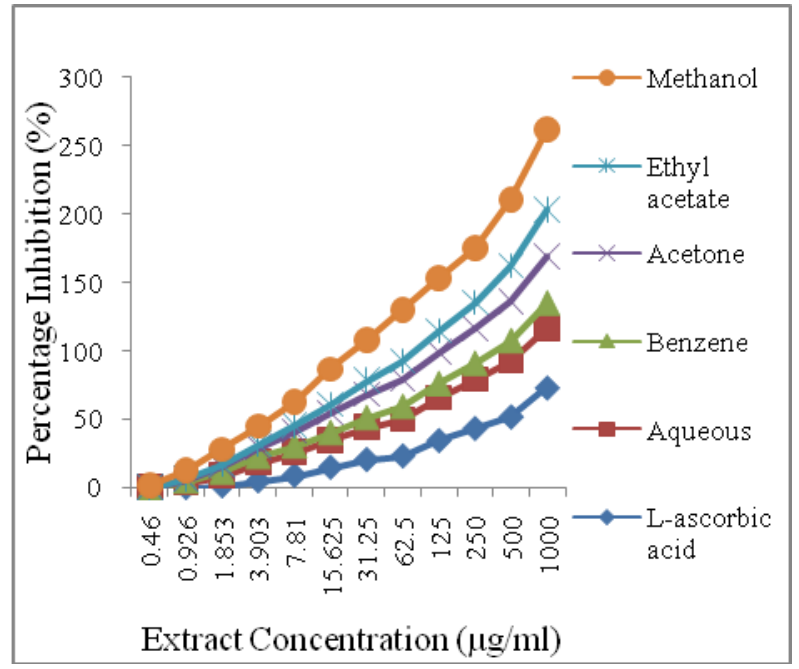

Fig. 4. The scavenging activity of aqueous and organic extracts of Aloe barbadensis and Lascorbic acid (standard) by Total antioxidant assay. The different concentrations of extracts used were 1000 to $0.46 \mu \mathrm{g} / \mathrm{mL}$. The data represent the percentage inhibition values and values are expressed as mean \pm $\mathrm{SD}(\mathrm{n}=3)$.

\section{E. Deoxyribose Method for Scavenging of Hydroxyl Radical}

The potentially reactive hydroxyl radicals can cause oxidative damage to DNA, lipids and proteins. The plant extract scavenge free radicals mediated by deoxyribose damage and was assessed by means of iron (II)-dependent DNA damage assay. Hydroxyl radical scavenging activity was measured by studying the competition between deoxyribose and the extracts for hydroxyl radicals generated from the $\mathrm{Fe} 2+/$ EDTA $/ \mathrm{H}_{2} \mathrm{O}_{2}$ system (Fenton reaction) ${ }^{(34)}$. The hydroxyl radicals attack deoxyribose which eventually results in thiobarbituric acid reacting substances (TBARS) formation. Deoxyribose degradation was measured as TBA reactive substances and the percentage of inhibition was calculated from the control where no test compound was added (2). The aqueous extract $A$. barbadensis showed strongest scavenging activity of $65.1 \pm 0.08$ and the other extracts gave their activity in the order of methanol > acetone > ethyl acetate extracts and the percentage inhibition values were found to be $60.2 \pm$ $0.16,48.6 \pm 0.81$ and $40.4 \pm 0.73$ percent respectively at the concentration of $1000 \mu \mathrm{g} / \mathrm{ml}$ of plant extract. The percentage inhibition value of standard, Lascorbic acid was found to be $53.7 \pm 0.08$ percent at concentration of $1000 \mu \mathrm{g} / \mathrm{ml}$. The benzene extract gave negative result by Deoxyribose method. The percentage inhibition values of $A$. barbadensis extracts by Deoxyribose method at different concentrations were shown in Figure 5.

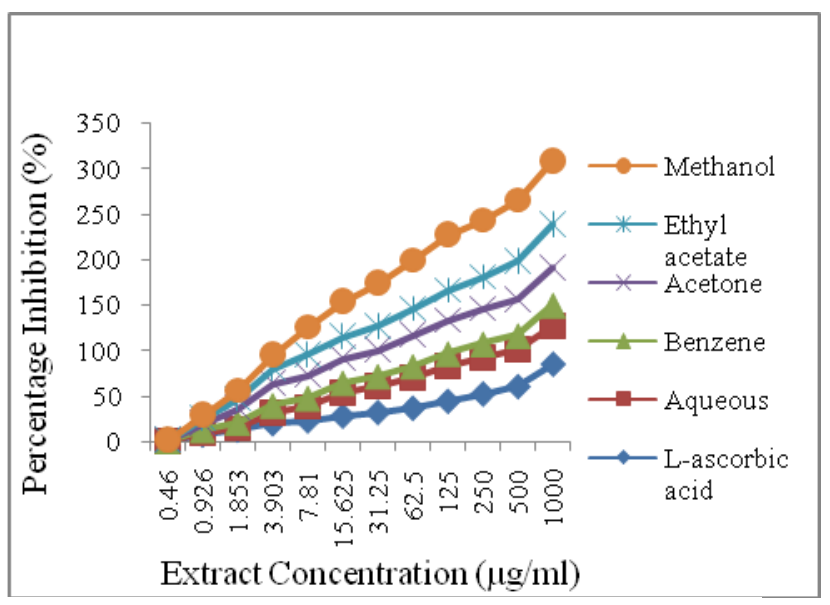

Fig. 5. The hydroxyl radical scavenging activity of aqueous and organic extracts of Aloe barbadensis and L-ascorbic acid (standard) by deoxyribose method. The different concentrations of extracts used were 1000 to $0.46 \mu \mathrm{g} / \mathrm{mL}$. The data represent the percentage inhibition values and values are expressed as mean $\pm \operatorname{SD}(n=3)$.

\section{F. Comparative Chart of $\mathrm{IC}_{50}$ Values of Aqueous and Organic Extracts}

The extracts of Aloe barbadensis also showed potent anti-oxidant activity by different methods. Comparative values of $\mathrm{IC}_{50}$ values of aqueous and organic extracts are given in table 1 . The present study shows acetone and methanolic extracts $A$. barbadensis showed anti-oxidant activity by DPPH radical scavenging assay with $\mathrm{IC}_{50}$ values of $705.2 \pm$ 8.08 and $182.8 \pm 1.44 \mu \mathrm{g} / \mathrm{ml}$ respectively. Whereas aqueous and methanolic extracts showed anti-oxidant activity by alkaline DMSO method with $\mathrm{IC}_{50}$ values of $237.5 \pm 11.4$ and $553.4 \pm 3.28 \mu \mathrm{g} / \mathrm{ml}$ respectively. While methanolic extract of A. barbadensis showed 
activity by nitric oxide method with $\mathrm{IC}_{50}$ value of $43.17 \pm 6.29 \mu \mathrm{g} / \mathrm{ml}$. The methanolic extract of $A$. barbadensis gave $\mathrm{IC}_{50}$ value of $589.6 \pm 5.54$ by total anti-oxidant activity and aqueous and methanolic extracts gave $\mathrm{IC}_{50}$ value of $579.8 \pm 3.95$ and $714.8 \pm$ $7.21 \mu \mathrm{g} / \mathrm{ml}$ respectively by deoxyribose method. Similarly, Ray and co-workers (2013), reported potent anti-oxidant activity in A. barbadensis by DPPH method, superoxide radical scavenging assay, hydroxyl radical scavenging assay, reducing power assay and metal chelating assay ${ }^{(30)}$. In other study, done by researchers on $A$. barbadensis found significant free radical scavenging activity by DPPH and ferric reducing anti-oxidant power (FRAP) assay (21).

\begin{tabular}{|c|c|c|c|}
\hline \multirow{2}{*}{$\begin{array}{l}\text { Extract } \\
\text { in } \\
\text { different } \\
\text { solvents }\end{array}$} & \multicolumn{3}{|c|}{ 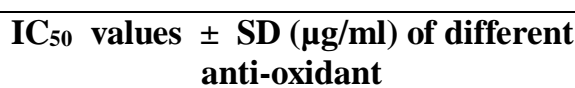 } \\
\hline & DPPH & $\begin{array}{l}\text { Alkaline } \\
\text { DMSO }\end{array}$ & $\begin{array}{l}\text { Nitric } \\
\text { oxide }\end{array}$ \\
\hline Aqueous & - & $237.5 \pm 11.4$ & - \\
\hline Acet & $705.2 \pm 8.08^{*}$ & - & - \\
\hline Methanol & $182.8 \pm 1.44^{*}$ & $553.4 \pm 3.28$ & $43.17 \pm 6.29$ \\
\hline
\end{tabular}

Table 1 Comparative chart of $\mathrm{IC}_{50}$ values of aqueous and organic extracts of Aloe barbadensis. Unit for $\mathrm{IC}_{50}$ for all the activities are $\mu \mathrm{g} / \mathrm{ml}$. Data are expressed as mean $\pm \mathrm{SD}(\mathrm{n}=3)$. ${ }^{*} \mathrm{p}<0.0001$ vs 0 $\mu \mathrm{g} / \mathrm{ml}$.

\begin{tabular}{|l|c|c|}
\hline \multirow{2}{*}{$\begin{array}{c}\text { Extract in } \\
\text { different } \\
\text { solvents }\end{array}$} & \multicolumn{2}{|c|}{$\begin{array}{c}\text { IC50 values } \pm \mathbf{S D}(\boldsymbol{\mu g} / \mathbf{m l}) \text { of } \\
\text { different anti-oxidant }\end{array}$} \\
\cline { 2 - 3 } & $\begin{array}{l}\text { Total anti-oxidant } \\
\text { capacity }\end{array}$ & Deoxyribose \\
\hline Aqueous & - & $579.8 \pm 3.95^{*}$ \\
\hline Acetone & - & - \\
\hline Methanol & $589.6 \pm 5.54^{*}$ & $714.8 \pm 7.21^{*}$ \\
\hline
\end{tabular}

Table 2 Comparative chart of $\mathrm{IC}_{50}$ values of aqueous and organic extracts of Aloe barbadensis. Unit for $\mathrm{IC}_{50}$ for all the activities are $\mu \mathrm{g} / \mathrm{ml}$. Data are expressed as mean $\pm \mathrm{SD}(\mathrm{n}=3)$. ${ }^{*} \mathrm{p}<0.0001$ vs 0 $\mu \mathrm{g} / \mathrm{ml}$.

\section{CONCLUSIONS}

The present study showed that the presence of phytochemicals is responsible for potent anti-oxidant activity in aqueous and organic extracts of Aloe barbadensis. The methanolic extract showed maximum activity as compared to other organic extracts screened. Further studies could be carried out for further purification and characterization of its compounds.

\section{ACKNOWLEDGMENTS}

We acknowledge Integral University for providing necessary facilities to perform research work. This work was supported financially by UGC, Maulana Azad National Fellowship.

\section{REFERENCES}

1. M. A. Abbasi, A. Raza, T. Riaz, T. Shahzadi, Aziz-ur-Rehman, M. Jahangir, D. Shahwar, S. Z. Siddiqui, A. R. Chaudhary and N. Ahmad, "Investigation on the volatile constituents of Juglans regia and their in vitro antioxidant potential," Proc. Pakistan Acad Sci, Vol. 47, No. 3, pp. 137-141, 2010.

2. H. M. Ali, A. Abo-Shady, H. A. S. Eldeen, H. A. Soror and W. G. Shousha, O. A. Abdel-Barry and A. M. Saleh, "Structural features, kinetics and SAR study of radical scavenging and antioxidant activities of phenolic and anilinic compounds," Chem Central J, Vol. 7, No. 53, 2013.

3. P. C. Trivedi, "Herbal Drugs and Biotechnology," Pointer Publishers, Jaipur, pp. 366, 2004.

4. N. Ara and H. Nur, "In vitro antioxidant activity of methanolic leaves and flowers extracts of Lippia Alba," Res J Medicine and Medical Sci, Vol. 4. No. 1, pp. 107-110, 2009.

5. S. Badami, S. R. Rai and B. Suresh, "Antioxidant activity of Aporosa lindleyana root," J Ethnopharmacol, Vol. 101 No. 1-3, pp.180-184, 2005.

6. M. S. Blois, "Antioxidant determinations by the use of a stable free radical," Nature, Vol. 181, pp. 1199-1200, 1958.

7. S. W. Choi, B. W. Son, Y. S. Son, Y. I, Park, S. K. Lee and M.H. Chung, "The wound-healing effect of a glycoprotein fraction isolated from Aloe vera," Br J Dermatol, Vol. 145, No. 4, pp. 535-545, 2001.

8. E. V. Christaki and P.C. Florou-Paneri, "Aloe vera: A plant for many uses," J Food Agric Environ, Vol. 8, No. 2, pp. 245-249, 2010.

9. P. Tiwari, B. Kumar, M. Kaur, G. Kaur and H. Kaur, "Phytochemical screening and Extraction: A Review," Int Pharm Sci, Vol. 1, No. 1, pp. 98106, 2011.

10. G. Tirzitis and G Bartosz, "Determination of antiradical and antioxidant activity: basic principles and new insights," Biochimica Polonica, Vol. 57, No. 1, pp. 139-142, 2010.

11. B. Halliwell, J. M. C. Gutteridge and O. J. Aruoma, "The deoxyribose method: A simple 
"test tube" assay for determination of rate constants for reactions of hydroxyl radicals," Anal Biochem, Vol. 165, No. 1, pp. 215-219, 1987.

12. K. Hegde and A. B. Joshi, "Preliminary phytochemical screening and antipyretic activity of Carissa spinarum root extract," Der Pharmacia letter, Vo. 2, No. 3, pp. 255-260, 2010.

13. I. Hinneburg, H. J. D. Dorman and R. Hiltunen, "Antioxidant activities of extracts from selzzected culinary herbs and spices," Food Chem, Vol. 97, pp. 122-129, 2006.

14. G. E. Trease and W. C. Evan, Pharmacognosy, Ed 12, English language Book society, Balliere Tindall, pp. 309-315 and 706-708.

15. Kirtikar and Basu, Indian medicinal plants. International book distributors. Vol IV; 2504 2506 and 2312-2314, 2007.

16. G. K. Jayaprakasha, T. Selvi and K. K. Sakariah, "Antibacterial and antioxidant activities of grape (Vitis vinifera) seed extracts," Food Res Int, Vol. 36, pp. 117-122, 2003.

17. M. Kammoun, S. Miladi, Y. B. Ali, M. Damak, Y. Gargouri and S. Bezzine, "In vitro study of the PLA2 inhibition and antioxidant activities of Aloe vera leaf skin extracts," Lipids Health Dis, Vol. 10, No. 30, 2011.

18. A. Kispotta, M. K. Shrivastava and M. Dutta, "Free radical scavenging activity of ethanolic extracts and determination of aloin from Aloe vera L leaf extract," Int J Aromatic plants, Vol. 2, No.4, pp. 612-618, 2012.

19. C. K. Kokate, A. P. Purohit and S. B. Ghokhale, Pharmacognosy, Nirali Prakashan, Pune, India, 1997.

20.E. Kunchandy and M. N. A. Rao, M.N.A, "Oxygen radical scavenging activity of curcumin.” Int J Pharm, Vol. 58, No. 3, pp. 237240), 1990.

21. A. Lopez, M. S. Tangil, O. Vega-Orellana, A. S. Ramírez and M. Rico, "Phenolic constituents, antioxidant and preliminary antimycoplasmic activities of leaf skin and flowers of Aloe vera (L.) Burm. f. (syn. A. barbadensis Mill.) from the Canary Islands (Spain)," Molecules, Vol. 18, pp. 4942-4954), 2013.

22. V. Mariapan and G. Shanthi, "Antimicrobial and phytochemical analysis of Aloe vera L," Int Res J Pharm, Vol. 3, No. 10, pp. 158-161, 2012.

23. J. Vaijanathappa, S. Badami and S. Bhojraj, "In vitro antioxidant activity of Enicostemma axillare," J Health Sci, Vol. 54, No. 5, pp. 524528, 2008.

24. M. A. Mir, S. S. Sawhney and M. M. S. Jassal, "Qualitative and quantitative analysis of phytochemicals of Taraxacum officinale," Wudpecker J Pharm Pharmocology, Vol. 2, No. 1, pp. 001-005, 2013.

25. E. A. K. Mohamed, "Antidiabetic, antihypercholesterolemic and antioxidative effect of Aloe vera gel extract in alloxan induced diabetic rats," Australian J Basic Applied Sci, Vol. 5, No. 11, 1321- 1327, 2011.

26. U. Nandal and R. L. Bhardwaj, Aloe vera for human nutrition, health and cosmetic use -A review, Int Res J Plant Sci, Vol. 3, No. 3, pp. 038046, 2012.

27. S. K. Nanyonga, A. Opoku, F. B. Lewu, A. O. Oyedeji and M. Singh, "Chemical composition, antioxidant activity and cytotoxicity of the essential oils of the leaves and stem of Tarchonanthus camphorates," African J Pharm Pharmacology, Vol. 7 No. 7, pp. 360-367, 2013.

28. P. Prieto, M. Pineda and M. Aguilar, "Spectrophotometric quantitation of antioxidant capacity through the formation of a phosphomolybdenum complex: specific application to the determination of vitamin E," Anal Biochem, Vol. 269, No. 2, pp. 337-341, 1999.

29. C. Proestos, K. Lytoudi, O. K. Mavromelanidou, P. Zoumpoulakis P and V. J. Sinanoglou, "Antioxidant capacity of selected plant extracts and their essential oils," Antioxidants, Vo. 2, pp. 11-22, 2013.

30. A. Ray, S. D. Gupta and S. Ghosh, "Evaluation of anti-oxidative activity and UV absorption potential of the extracts of Aloe vera L. gel from different growth periods of plants," Ind Crops Prod, Vol. 49, pp. 712-719, 2013.

31. S. D. Sanja, N. R. Sheth, N. K. Patel, D. Patel and B. Patel, "Characterization and evaluation of antioxidant activity of Potulaca oleracea," Int J Pharm Pharmaceutical Sci, Vol. 1, No. 1, pp. 7484, 2009.

32.S. Shamim, S. W. Ahmed and I. Azhar, "Antifungal activity of Allium, Aloe, and Solanum species, Pharm Biol, Vol. 42 No. 7, pp. 491-498, 2004.

33. H. D. Sharma, "Hepatoprotective potential of Aloe barbadensis Mill. against carbon tetrachloride induced hepatotoxicity," Int J Res Pharmaceutical Biomedical Sci, Vol. 3, No. 3, pp. 1119- 1124, 2012.

34. S. Stohs and D Bagchi, "Oxidative mechanisms in the toxicity of metal ions," Free Radical Biol Medicine, Vol. 18, No. 2, pp. 321-336, 1995. 